Article

\title{
Serum Protein Electrophoretic Pattern in Neonatal Calves Treated with Clinoptilolite
}

\author{
Simona Marc ${ }^{1}$, Danijela Kirovski ${ }^{2}$, Călin Mircu ${ }^{1}$, Ioan Hutu ${ }^{1}$, Gabriel Otavă ${ }^{1}$, Cristina Paul ${ }^{3}$, \\ Oana Maria Boldura ${ }^{1}$ and Camelia Tulcan ${ }^{1, *}$ \\ 1 Faculty of Veterinary Medicine, University of Agricultural Sciences and Veterinary Medicine "King Michael \\ I" of Banat Timişoara, Calea Aradului 119, 300645 Timişoara, Romania; simo20_med@yahoo.com (S.M.); \\ calinmircu@yahoo.com (C.M.); ioan.hutu@yahoo.com (I.H.), gabiotava@yahoo.com (G.O.), \\ oanaboldura@gmail.com (O.M.B.) \\ 2 Faculty of Veterinary Medicine, University of Belgrade, Bulevar Oslobodenja 18, 11000 Belgrade, Serbia; \\ dani@vet.bg.ac.rs \\ 3 Faculty of Industrial Chemistry and Environmental, University Politehnica Timisoara, Carol Telbisz 6, \\ 300001 Timisoara, Romania; cristina.paul@upt.ro \\ * Correspondence: tulcancamelia@gmail.com; Tel.: +40-722-584-583
}

Received: 2 May 2018; Accepted: 24 May 2018; Published: 26 May 2018

\begin{abstract}
The objective of our study was to determine the effects of clinoptilolite supplemented in colostrum on the blood serum protein electrophoretic pattern of new-born calves. Methods: Romanian Black and White new-born calves involved in the study were divided into 3 groups: the control group (C) that received colostrum without clinoptilolite, and experimental groups I (E1) and II (E2) that received colostrum supplemented with $0.5 \%$ and $2 \%$ clinoptilolite, respectively. The concentration of total protein and protein fractions (albumin, $\alpha 1$-globulin, $\alpha 2$-globulin, $\beta$-globulin and $\gamma$-globulin) were analyzed by electrophoresis on cellulose acetate. Results: At hour 30 after birth, concentrations of $\gamma$-globulins, $\beta$-globulin and total protein in E1 group of calves were higher than in control group by $42.11 \%(p<0.05), 28.48 \%(p>0.05)$ and $18.52 \%(p>0.05)$, respectively, and were higher, but not significantly, in group E2 compared to the control group. This was in accordance with a significant lower albumin/globulin ratio in groups E1 and E2 (29.35\%, $p<0.05$ and 35.87\%, $p<0.05$, respectively) than in control group at $30 \mathrm{~h}$ postpartum, which indicates an obvious increase of the globulins fraction in experimental groups. The conclusion: Clinoptilolite was effective in improving passive transfer in new-born calves, but it was more effective if added in colostrum with a dose of $0.5 \%$ than with a dose of $2 \%$.
\end{abstract}

Keywords: electrophoresis; calves; clinoptilolite; $\gamma$-globulin

\section{Introduction}

Gut immunoglobulins absorption is time limited, since the permeability of enterocytes is highest at birth, and is reduced by $50 \%$ during the next $6 \mathrm{~h}$, due to intestinal cells maturation in newborns, i.e., mature cells population does not alow macromolecules transfer and their lysozyme activity increases progressively leading to enzymatic digestion of immunoglobulins [1,2].

Factors that affect the level of colostrum immunoglobulins absorbtion are time of the first colostrum feeding after birth, quality and quantity of colostrum, pattern of taking the colostrum, bacterial contamination of colostrum, dam's lactation number, breed, season of calving, dam's dry period length, maternity microclimate and immunity status of dam. If one or several of those factors are disturbed, the failure of the transfer of passive immunity (FPT) in newborns occurs. The incidence of FPT is high in young ruminants leading to a high incidence of neonatal morbidity and mortality, with possible reduced weight gain and increased drug use which cause huge economic loss on dairy farms [3-6]. 
Colostrum quality improvement may enhance immunoglobulin absorption [3]. Supplementation of colostrum with clinoptilolite, a natural zeolite, is a natural method to improve immunoglobulin absorption in newborn calves [7-10]. Zeolites are crystalline, hydrated aluminosilicate of alkali and alkaline earth cations having three dimensional structure [11]. Due to their unique properties (cation exchange, adsorption or acting as molecular sieves, catalytic, dehydration/rehydration and biological reactivity), zeolites are used in a wide range of biological processes in human and veterinary fields where they have antiviral effects [12], antitumoral effects [13,14] and antioxidant effects [15]. In addition, they are used in the prevention and/or treatment of certain farm animal diseases [16,17].

Immunoglobulin concentrations in blood serum can be evaluated through electrophoretic techniques, due to the migration of the last fraction, $\gamma$-globulins. Serum electrophoretic method is not commonly used in bovine practices, although in small animals it is used as a laboratory diagnostic technique for protein metabolism. Studies in ruminants revealed factors that may have influenced the results, such as the physiological status of the animal and its age, as well as laboratory pre-analytical preparations of the samples [18-21].

The aim of this study is to analyse the effects of short-term clinoptilolite supplementation added in two different doses in colostrum on serum protein levels in newborn calves, especially on the immunoglobulins, analysed by electrophoretic method.

\section{Results}

The calves in all groups had a significant increase in the concentration of total protein in time, but there was no significant difference between groups $30 \mathrm{~h}$ postpartum $(p>0.05)$. Albumin concentrations did not significantly change after consuming colostrum, and were no different between groups at $30 \mathrm{~h}$ postpartum $(p>0.05)$. The time and group influence on $\alpha 1$ and $\alpha 2$-globulin fractions was not recorded at $30 \mathrm{~h}$ postpartum, except for the $\alpha 1$ globulin fraction in E2 that decreased at $30 \mathrm{~h}$ as compared to $6 \mathrm{~h}$ $(p<0.02) . \beta$-globulin fractions showed significant increases in all groups $(\mathrm{E} 1, \mathrm{E} 2, \mathrm{C})$ in comparison with birth time $(p<0.05)$, but there were no statistical differences in concentration of this fraction between groups $30 \mathrm{~h}$ postpartum $(p>0.05) . \gamma$-globulins percentage was significantly higher in E1 compared to the control group at $30 \mathrm{~h}$ of life $(p<0.05)$, but not in the E2 group $(p>0.05)$ (see Table 1 and Figure 1 ).

Table 1. Total protein concentration and protein fractions ( $x \pm \mathrm{SE} ; \mathrm{g} / \mathrm{L})$ in blood serum of calves.

\begin{tabular}{|c|c|c|c|c|c|}
\hline Parameters & Group & Parturition & $6 \mathrm{~h}$ & $16 \mathrm{~h}$ & $30 \mathrm{~h}$ \\
\hline \multirow{3}{*}{ Total protein $(\mathrm{g} / \mathrm{L})$} & $\mathrm{C}$ & $42.65 \pm 6.26$ & $55.40 \pm 5.28$ & $74.03 \pm 3.89^{*, * *}$ & $76.17 \pm 6.54^{* * * *}$ \\
\hline & E1 & $46.40 \pm 1.32$ & $72.23 \pm 7.12 *$ & $84.35 \pm 4.50^{* * * *}$ & $90.28 \pm 4.75^{*, * *}$ \\
\hline & E2 & $38.28 \pm 5.65$ & $54.73 \pm 10.73$ & $66.40 \pm 12.53 *$ & $81.88 \pm 3.96^{*, * *}$ \\
\hline \multirow{3}{*}{ Albumin (g/L) } & $\mathrm{C}$ & $32.86 \pm 4.67$ & $27.69 \pm 3.74$ & $32.47 \pm 3.28$ & $36.43 \pm 3.57$ \\
\hline & E1 & $33.36 \pm 1.32$ & $34.72 \pm 8.52$ & $32.88 \pm 4.33$ & $34.86 \pm 1.97$ \\
\hline & E2 & $28.69 \pm 4.68$ & $25.94 \pm 5.02$ & $23.42 \pm 3.83$ & $29.16 \pm 3.15$ \\
\hline \multirow{3}{*}{ «1-globulin (g/L) } & $\mathrm{C}$ & $1.40 \pm 0.21$ & $1.54 \pm 0.33$ & $2.42 \pm 0.40$ & $2.71 \pm 0.48$ \\
\hline & E1 & $2.54 \pm 0.61$ & $2.06 \pm 0.84$ & $4.23 \pm 1.78$ & $4.04 \pm 0.56$ \\
\hline & E2 & $0.94 \pm 0.18$ & $1.12 \pm 0.28$ & $0.83 \pm 0.19$ & $2.32 \pm 0.60 *$ \\
\hline \multirow{3}{*}{ «2-globulin (g/L) } & $\mathrm{C}$ & $2.43 \pm 0.57$ & $3.82 \pm 1.31$ & $4.23 \pm 1.69$ & $2.24 \pm 0.36$ \\
\hline & E1 & $4.15 \pm 2.01$ & $8.10 \pm 1.85$ & $4.48 \pm 0.57$ & $2.98 \pm 0.19$ \\
\hline & E2 & $4.01 \pm 0.32$ & $5.72 \pm 1.12$ & $5.33 \pm 1.67$ & $3.66 \pm 0.96$ \\
\hline \multirow{3}{*}{$\beta$-globulin (g/L) } & $\mathrm{C}$ & $4.41 \pm 1.34$ & $6.89 \pm 1.58$ & $7.03 \pm 1.17$ & $7.83 \pm 0.85^{*}$ \\
\hline & E1 & $5.13 \pm 1.20$ & $8.56 \pm 1.27$ & $8.71 \pm 0.40$ & $10.06 \pm 0.74 *$ \\
\hline & E2 & $4.08 \pm 0.83$ & $8.14 \pm 1.24^{*}$ & $8.71 \pm 2.49$ & $9.28 \pm 0.52 *$ \\
\hline \multirow{3}{*}{$\gamma$-globulin (g/L) } & $\mathrm{C}$ & $1.50 \pm 0.48$ & $15.86 \pm 4.06^{*}$ & $27.83 \pm 3.85^{* * * *}$ & $26.95 \pm 2.84^{*, * *}$ \\
\hline & E1 & $0.68 \pm 0.26$ & $18.68 \pm 3.56^{*}$ & $34.03 \pm 3.32 * * *$ & $38.30 \pm 4.19^{* * *, a}$ \\
\hline & E2 & $0.57 \pm 0.18$ & $13.81 \pm 4.87^{*}$ & $28.01 \pm 7.48^{*, * *}$ & $37.47 \pm 4.77^{* * * *}$ \\
\hline \multirow{3}{*}{$\mathrm{A} / \mathrm{G}$} & $\mathrm{C}$ & $3.90 \pm 0.67$ & $1.16 \pm 0.24 *$ & $0.85 \pm 0.14^{*, * *}$ & $0.92 \pm 0.06^{*, * *}$ \\
\hline & E1 & $3.04 \pm 0.50$ & $1.02 \pm 0.30 *$ & $0.66 \pm 0.12^{*, * *}$ & $0.65 \pm 0.08^{* * * *, \mathrm{a}}$ \\
\hline & E2 & $2.88 \pm 0.27$ & $0.92 \pm 0.08 *$ & $0.60 \pm 0.06^{* * * *}$ & $0.59 \pm 0.10^{*, * *, \mathrm{a}}$ \\
\hline
\end{tabular}

Significant differences $(p<0.05)$ inside the group: ${ }^{*}$ vs. parturition, ${ }^{* *}$ vs. $6 \mathrm{~h}$, Significant differences $(p<0.05)$ between the groups: ${ }^{\mathrm{a}}$ at $30 \mathrm{~h}$ (E1 vs. C). 


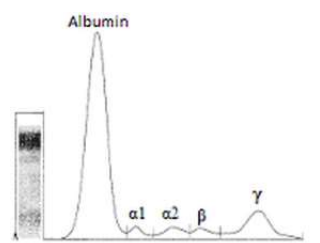

a) $C$ group at parturition

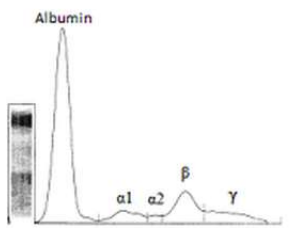

e) E1 group at parturition

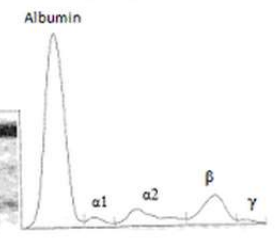

i) E2 group at parturition

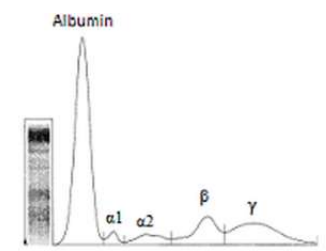

b) $\mathrm{C}$ group at $\mathrm{hh}$

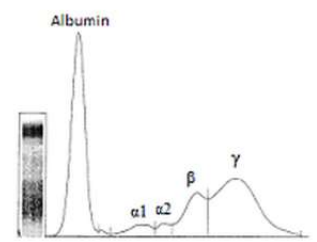

f) E1 group at $6 \mathrm{~h}$

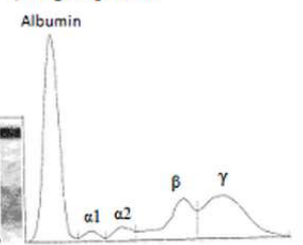

j) E2 group at $6 h$
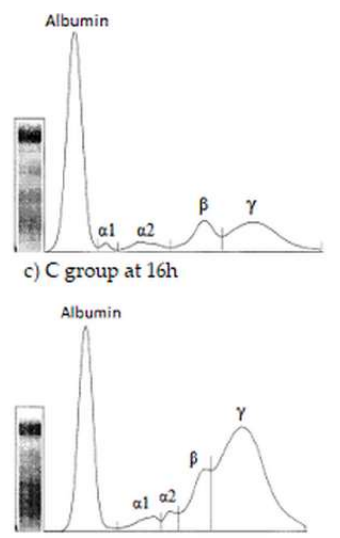

g) E1 group at $16 \mathrm{~h}$

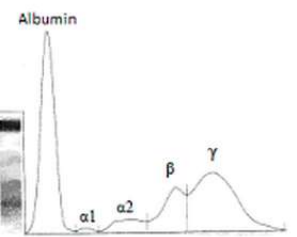

k) E2 group at 16h

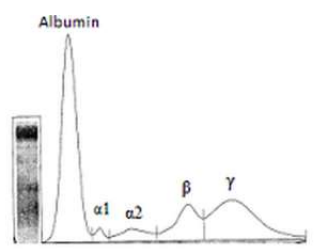

d) $\mathrm{C}$ group at $30 \mathrm{~h}$

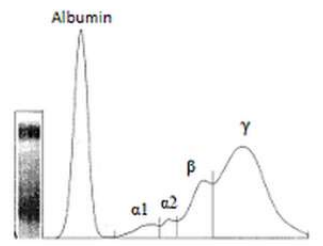

h) E1 group at 30h

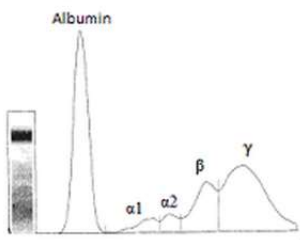

1) E2 group at $30 \mathrm{~h}$

Figure 1. Representative serum protein electrophoretograms observed in calves from C, E1 and E2 groups during parturition, at 6,16 and $30 \mathrm{~h}$ postpartum. (a) $\mathrm{C}$ group at parturition. (b) $\mathrm{C}$ group at $6 \mathrm{~h}$ postpartum. (c) C group at $16 \mathrm{~h}$ postpartum. (d) C group at $30 \mathrm{~h}$ postpartum. (e) E1 group at parturition. (f) E1 group at $6 \mathrm{~h}$ postpartum. (g) E1 group at $16 \mathrm{~h}$ postpartum. (h) E1 group at $30 \mathrm{~h}$ postpartum. (i) E2 group at parturition. (j) E2 group at 6h postpartum. (k) E2 group at 16h postpartum. (1) E2 group at 30h postpartum.

In addition, there was a positive correlation between total protein and $\gamma$-globulin concentrations at $30 \mathrm{~h}$ postpartum in groups E1 and E2, but not in group C (Figure 2).

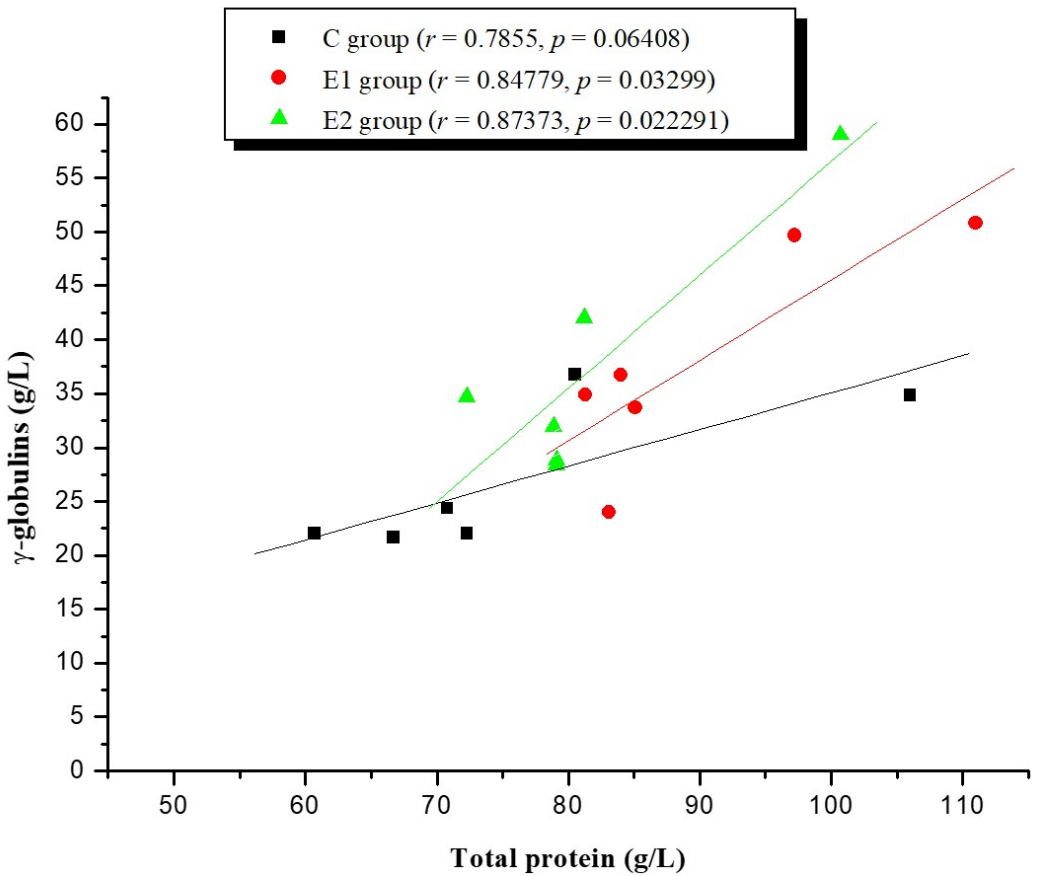

Figure 2. Relation between total proteins and $\gamma$-globulins concentrations in calves at $30 \mathrm{~h}$ postpartum. 


\section{Discussion}

Serum total protein concentration is an indicator of the successful transfer of passive immunity in calves, because there is a positive relationship between such a parameter and immunoglobulins. The adequate passive transfer of immunoglobulins in calves is considered when total protein concentrations at $24 \mathrm{~h}$ postpartum is more than $52 \mathrm{~g} / \mathrm{L}$, which is equivalent to $10 \mathrm{~g} / \mathrm{L} \mathrm{IgG} \mathrm{[6].}$ Thus, there was no FPT in any of examined groups of calves in our study, since all of calves had a concentration of total protein higher than $54 \mathrm{~g} / \mathrm{L}$ and serum $\gamma$-globulins higher than $10 \mathrm{~g} / \mathrm{L}$ starting with the administration of first colostrum.

The colostrum used in this experiment was from Romanian Black and White cows that were in 2nd to 4th lactation. Weaver et al. (2000) [6] suggested that cows that were in 1st to 4th lactation provide high-quality colostrum to their calves, meaning that the calves in our study received high-quality colostrum. According to our previous results based on chemical composition of colostrum of cows [22], compared to high-yielding breeds (Holstein), autohtonious breeds, even if they have lower daily milk production (12 L in our study), have a better quality of colostrum. Total protein levels determined in blood serum of calves reflect both the level of colostrum ingested and the effects of clinoptilolite on immunoglobulin absorption. The method of colostrum administration can affect the efficiency of colostral immunoglobulins transfers, since the highest percent of calves that suffer from FPT are those that suckle their dams (61.4\%), while only 19.3\% of calves with FPT are fed by bottle and $10.8 \%$ are fed by tube [4]. The calves from our study received their first colostrum within $2 \mathrm{~h}$ after parturition, because immediately after birth calves are not able to ingest adequate amounts of colostrum and because they need some time to acclimate to an extra uterine environment. According to the literature [6], the time of ingestion is positively correlated with the cessation of colostral immunoglobulins absorption from the intestine.

After consuming colostrum, serum $\gamma$-globulins fractions increased significantly in all groups of calves, in comparison with time of birth, when the serum levels of $\gamma$-globulins were almost nonexistent $(p<0.05)$, which highlights the lack of transplacental transfer of immunoglobulins and the importance of colostrum on passive transfer success. In addition, at $30 \mathrm{~h}$ after birth, experimental groups had higher concentration of serum $\gamma$-globulins fractions compared to control, significant in group E1 $(p<0.05)$.

Data from the literature offers us some possible explanations of clinoptilolite action on intestinal absorption of colostral immunoglobulins: (a) reduced negative impact of food decomposition process in intestines on mucosal epithelial cells that are involved in absorption of intact molecules of colostrum immunoglobulins; (b) possible adsorption of enteropathogens that colonize the digestive tract of the calf in the first hours after parturition thus limiting its attachement to the intestinal cell-membrane receptors and (c) increased the amount of absorption by increasing the length of enterocytes microvilli and reducing diameter thereof $[16,23]$.

Decreased albumin level in experimental groups compared with control group showed that the $\mathrm{A} / \mathrm{G}$ is in favor of globulins, which means a high level of absorption of colostral $\gamma$-globulins during the first $30 \mathrm{~h}$ postpartum.

$A / G$ is another parameter that highlights changes in serum globulin concentrations in calves. Thus a fall in the $A / G$ in the first hours after birth in calf serum signifies an increase in the globulin fraction. The significant decrease in the A/G at $30 \mathrm{~h}$ postpartum recorded in E1 and E2 groups indicates a better passive transfer of $\gamma$-globulins in calves from groups E1 and E2, possibly due to clinoptilolite added in colostrum.

Analyzing all five protein fractions, only the last one, $\gamma$-globulin, had a proportional increase time/dose, while the others increased inconstant. The $\alpha 1$ and $\alpha 2$ globulin fractions recorded variations after the administration of colostrum to all studied calves without influence of clinoptilolite. Higher $\beta$-globulin fractions in the experimental groups (E1, E2) as compared to control group (E1/C: $+28.48 \%$, $\mathrm{E} 2 / \mathrm{C}:+18.52 \%)(p>0.05)$ at $30 \mathrm{~h}$ after birth, means that the administration of clinoptilolite resulted in a significant increase in immunoglobulins $A$ and $M$, because such types immunoglobulins have $\beta$ 
globulinic mobility $[2,24]$. Our results were similar those of Reference $[7,8]$ and different from those of Reference [5]. Mohri et al. (2008) suggested that following clinoptilolite supplementation at a rate of $2 \%$ for $48 \mathrm{~h}$ in colostrum and $1 \%$ for 14 days in colostrum and milk, serum total protein, $\gamma$ and $\beta$ globulin, except albumin were not significantly affected by supplementation. A possible explanation of increased albumin might be found in ensuring a more efficient digestion of milk proteins and a higher uptake of amino acids, which increased the hepatic albumin synthesis [5].

The interval chosen for blood serum collection $(0,6,16$ and $30 \mathrm{~h}$ postpartum) represents the interval of $4-6 \mathrm{~h}$ after administration of colostrum with/without clinoptilolite, which is the necessary time for the absorption of macromolecules in the intestine. We have stopped examination at $30 \mathrm{~h}$ postpartum (that means $6 \mathrm{~h}$ after administration of colostrum that occured $24 \mathrm{~h}$ postpartum), because it was reported that until hour 36 postpartum, the calf's small intestine enterocytes would nonselectively absorb macromolecules [6]. We know from data from the literature that after $48 \mathrm{~h}$ postpartum, the values of calves gammaglobulins tend to stabilise and at about 4 weeks of age calves starts their own immunoglobulin synthesis $[2,7-9,25,26]$. Administration of clinoptilolite for a longer period of time (14 days) did not influence the level of calf's serum $\gamma$-globulins [5,27].

There are many factors that influence serum immunoglobulins concentration in calves during the first $24-48 \mathrm{~h}$ postpartum. One is the apparent efficiency of absorption (AEA), the efficiency with which ingested colostral IgG is absorbed in circulation. Absorption efficiency is apparent because about $50 \%$ of IgG absorbed will pass in extravascular spaces, therefore, theoretically, the AEA goes up to $50 \%$ [28]. The absorption of IgG intake is effective when the AEA mean is around $25-35 \%$ [28]. The AEA observed in this study was effective for all groups, but slightly better for calves in group E1.

Although the concentration of $\gamma$-globulins fraction in blood serum of control group $(26.95 \pm 2.84 \mathrm{~g} / \mathrm{L})$ was high enough to protect the newborn calves from infection, the calves in this group had more gastraintestinal disorders (diarrhoea) in the first 28 postnatal days and the average weight was lower than in calves from experimental groups at 45 days postpartum [29]. Such data and those of $[27,30]$ highlights the idea that health status of calves in their first weeks of life is influenced by the level of serum $\gamma$-globulins.

Some mechanisms supporting the effect of the dietary use of zeolites on diarrhoea syndrome include: (a) possible stimulation of the defense line of the intestinal tract, causing the animal to produce more antibodies; (b) acting as a water adsorber or having a retarding effect on the intestinal rate [31]; (c) regulation of gut $\mathrm{pH}$ [11]; (d) binding of enterotoxins implicated in gastrointestinal disturbances; (e) changing metabolic acidosis through effects on osmotic pressure in the intestinal lumen [16]; (f) having adsorption effects on bile acids, one of endogenic causes of diarrhoea, as well as on aflatoxin $\mathrm{B}_{1}$ and glucose, that in high content in intestinal fluid acts as irritant factor and whose transport through the intestinal cells is reversed during diarrhoea [32]; $(\mathrm{g})$ possible adsorption of dietary substances, which may result in intestinal hypersensitivity to feed antigens, possible maintaining or restoring the digestive enzyme activity $[16,33]$.

The beneficial impacts of clinoptilolite on protein metabolism were demonstrated by the determination of hormones which act by stimulating the protein synthesis (insulin) or by increasing protein catabolism (thyroid hormones). Adding of natural zeolite (clinoptilolite) to colostrum caused considerable increase of IGF-1 and insulin in the blood serum of newborn piglets [34] and decreased thyroid hormone concentrations in newborn calves [35]. Such results indicate the possible beneficial effect on timely regulation of energy balance in newborns, by increasing the rate of resorption of nutrients in colostrum, providing newborn animals with sufficient energy.

It is well known that adding mineral adsorbant into feed has beneficial effects. Mumpton (1999) described the role of zeolites in the gastrointestinal tract where they actas an ammonium reservoir, thereby allowing the animal to use ingested nitrogen more efficiently. Also ammonium containing zeolite may support the growth of nitrogen-loving bacteria that contribute to the health of the animals. This property of zeolites is important in young animals because their feed contains a high level of 
proteins and it may be concluded that zeolite could be vital for the digestion process and nutritive substances absorption even after the colostrum period [11].

\section{Materials and Methods}

\subsection{Animals Experiment}

The study was carried out on 18 newborn Romanian Black and White calves in Didactic Farm of Banat's University of Agricultural Sciences and Veterinary Medicine "King Michael I" in Timişoara. The study was performed in compliance with national (471/2002) and international (Directive 86/609 CEE) laws regarding animal welfare and ethics in animal experiments. The approval of experiments was given by University Coomision of Ethics , USAMVBT-PG-001-R021/2014. Calves were separated from the dams within 20-30 min after parturition, and were weighed and transferred to the calf area. Calves were divided into 3 groups based on birth order: Control group $(C, n=6)$ and two experimental groups (E1, $n=6$; E2, $n=6)$. Calves were bottle fed with the first colostrum $(1.5 \mathrm{~L})$ within $2 \mathrm{~h}$ after birth and after that two times daily, at $12 \mathrm{~h}$ interval, with the same quantity of colostrum that was milked at $12 \mathrm{~h}$ interval. We have chosen bottle feeding, which is the most common feeding on commercial dairy farms, due to the fact that in that way we could control the quantity of colostrum ingested by the calf and we could add clinoptilolite to colostrum.

Calves in first experimental group (E1) received colostrum with $0.5 \%$ clinoptilolite, within $2 \mathrm{~h}$ after birth, at 12 and $24 \mathrm{~h}$. In the second experimental group (E2), calves received $2 \%$ clinoptilolite in the same interval as the first experimental group.

The blood samples were collected from jugular vein in vacutainer tubes prior to colostrum intake, at 6,16 and $30 \mathrm{~h}$ after birth. Blood serum was obtained after centrifugation of the samples at $3000 \times g$ for $5 \mathrm{~min}$ and stored at $-20^{\circ} \mathrm{C}$ until analysis.

\subsection{Clinoptilolite}

The commercial product of clinoptilolite (Min-a-Zel S, Patent Komerc, Belgrade, Serbia) was used in present study. The Min-a-Zel S, as a natural zeolite, contains minimum $85 \%$ clinoptilolite. Granulometry of clinoptilolite is $100 \%<300 \mu \mathrm{m}$. The chemical analysis of the product was determined at ITNMS (Institute for the Application of Nuclear Energy), Belgrade, Serbia.

\subsection{Quantitative Analysis of Total Protein}

Serum total protein content was determined on clinical chemistry automatic analyzer (EOS BRAVO FORTE Hospitex Diagnostics, Fiorentiono, Italy) by biuret colorimetric method using dedicated commercially reagent kit, REF. 4001950L (Hospitex Diagnostics, Fiorentino, Italy). Internal quality control was performed with reference materials (calibrator, control serum with normal and pathological values) from the same producer (REF 40011935, 40011925 respectively 40011930). Colostrum IgG were analyzed by radial immunodifussion method by commercially available kits (INEP ZEMUN, Belgrade, Serbia).

\subsection{Electrophoresis Analysis of Serum Protein Fractions}

Protein fractions (albumin, $\alpha 1$-globulin, $\alpha 2$-globulin, $\beta$-globulin and $\gamma$-globulin) were analyzed by electrophoresis on Mylar ${ }^{\circledR} 35 \times 76 \mathrm{~mm}$ backed cellulose acetate strips by kits for determining serum protein (code SRE174K, INTERLAB, Rome, Italy) with Genio electrophoresis automatic analyzer. $30 \mu \mathrm{L}$ of the sample was subjected to the microtechnique assay with following method parameters: sample application time $10 \mathrm{~s}$, migration time $15 \mathrm{~min}$., staining time $300 \mathrm{~s}$, destaining time $180 \mathrm{~s}$, clearing time $120 \mathrm{~s}$, drying time $620 \mathrm{~s}$, migration voltage $140 \mathrm{~V}$ with an optical density scanning green light.

For controlling measurement accuracywe used normal serum control (REF:SCE123A) and pathological serum control (REF:SCE126A). The automated system was regularly monitored for accuracy and precision in accordance with "Good laboratory practice" guidelines. 
Serum concentration of protein fraction $(\mathrm{g} / \mathrm{L})$ was obtained according to relationship:

$$
\text { Concentration of protein fraction }(\mathrm{g} / \mathrm{L})=\frac{\text { total protein } \mathrm{x} \text { protein fraction }}{100}
$$

Albumin/globulins ratio (A/G) was obtained according to relationship:

$$
\mathrm{A} / \mathrm{G} \text { ratio }=\frac{\text { albumin concentration }}{\sum \text { globulins concentration }}
$$

Apparent efficiency of absorption (AEA) of $\gamma$ globulins was calculated by taking into account the quantity and quality of colostrum ingested and the volume of calf serum. Plasmatic volume was calculated as being $9.1 \%$ of body weight [22].

$$
\text { AEA }(\%)=\frac{\text { serum IgG concentration } x \text { plasmatic volume }}{\operatorname{IgG} \text { consumed }} \times 100
$$

\subsection{Statistical Analysis}

The results obtained were processed using the statistical software MINITAB 13 (licenced for USAMVBT, Timisoara, Romania). Values are expressed as means with standard error ( $x \pm \mathrm{SE}$ ). Results were evaluated using a one way analysis of variance (ANOVA) with 3 variables (calf, treatment, and time). Whenever the ANOVA revealed significat $F$ values for such variables, a $t$-test was used for pos hoc comparation. Results were deemed as statistically significant when a $p$ value was $<0.05$.

\section{Conclusions}

Supplementation of colostrum with clinoptilolite has a positive influence on serum $\gamma$-globulin fractions and total protein concentration in neonatal dairy calves, with better results obtained by adding $0.5 \%$ rather than $2 \%$ clinoptilolite.

Author Contributions: Conceptualization, S.M. and D.K.; Data curation, S.M.; Formal analysis, I.H.; Investigation, D.K., C.M., G.O., C.P., O.M.B. and C.T.; Methodology, D.K., I.H. and C.T.; Project administration, C.T.; Resources, C.M., G.O. and C.P.; Validation, O.M.B. and C.T.; Visualization, I.H.; Writing—original draft, S.M.; Writing—review \& editing, C.T.

Funding: We have been able to carry out this research with the support of Interdisciplinary Research Platform and Research Laboratory Center Horia Cernescu founded by infrastructure project POSCCE SMIS 2669, belonging to Banat University of Agricultural Sciences and Veterinary Medicine "King Michael I of Romania" from Timisoara.

Acknowledgments: We would like to thank PATENT KOMERC, Serbia for providing us the product Min-a-Zel S.

Conflicts of Interest: The authors declare no conflict of interest.

\section{References}

1. Davis, C.L.; Drackley, J.K. The Development, Nutrition and Management of the Young Calf; Iowa State University Press: Iowa City, IA, USA, 1998; pp. 180-205. ISBN 9780813829807.

2. Tizard, I.R. Immunity in the fetus and newborn. In Veterinary Immunology. An Introduction, 4th ed.; W.B. Saunders College Publishing: Philadelphia, PA, USA, 1992; pp. 248-260. ISBN 0-7216-4686-7.

3. Blattler, U.; Hammon, H.M.; Morel, C.; Philipona, C.; Rauprich, A.; Rome, V.; Le Huerou-Luron, I.; Guilloteau, P.; Blum, J.W. Feeding colostrum, its composition and feeding duration variably modify proliferation and morphology of the intestine and digestive enzyme activities of neonatal calves. J. Nutr. 2001, 131, 1256-1263. [CrossRef] [PubMed]

4. Chigerwe, M.; Tyler, J.W.; Summers, M.K.; Middleton, J.R.; Schultz, L.G.; Nagy, D.W. Evaluation of factors affecting serum IgG concentrations in bottle-fed calves. J. Am. Vet. Med. Assoc. 2009, 234, 785-789. [CrossRef] [PubMed] 
5. Mohri, M.; Seifi, H.A.; Daraei, F. Effects of short-term supplementation of clinoptilolite in colostrum and milk on hematology, serum proteins, performance, and health in neonatal dairy calves. Food Chem. Toxicol. 2008, 46, 2112-2117. [CrossRef] [PubMed]

6. Weaver, D.M.; Tyler, J.W.; Van Metre, D.C.; Hostetler, D.E.; Barrington, G.M. Passive transfer of colostral immunoglobulins in calves-review. J. Vet. Intern. Med. 2000, 14, 569-577. [CrossRef] [PubMed]

7. Fratrić, N.; Stojić, V.; Janković, D.; Šamanc, H.; Gvozdić, D. The effect of a clinoptilolit based mineral adsorber on concentrations of immunoglobulin $\mathrm{G}$ in the serum of newborn calves fed different amounts of colostrum. Acta Vet. 2005, 55, 11-21.

8. Fratrić, N.; Stojić, V.; Rajcić, S.; Radojičić, B. The effect of mineral adsorbent in calf diet colostrum on the levels of serum immunoglobulin G, protein and glucose. Acta Vet. 2007, 57, 169-180.

9. Gvozdić, D.; Stojić, V.; Fratrić, N.; Pesut, O.; Jovanović, I.; Kirovski, D.; Šamanc, H.; Vujanać, I. Eficiency of immunoglobulin absorption in newborn calves receiving oral clinoptilolite treatement. Sci. Pap. Vet. Med. Timis. 2007, XL, 234-242.

10. Step, D.S.; Litherland, N.B.; Burciaga-Roble, O.; Breshears, M.; Krehbiel, C.R.; Confer, A.W.; Fulton, R.W.; Morgan, G.L.; Thornsberry, M.; Fassig, S.M. Clinical observations, biochemical data and postmortem and histopathologic findings in young dairy calves fed zeolite clinoptilolite binder combined with milk replacer. Am. J. Vet. Res. 2008, 69, 1587-1594. [CrossRef] [PubMed]

11. Mumpton, F.A. La roca magica: Uses of natural zeolites in agriculture and industry. Proc. Natl. Acad. Sci. USA 1999, 96, 3463-3470. [CrossRef] [PubMed]

12. Grace, M.; Pavelic, K. Antiviral properties of clinoptilolite. Microporous Mesoporous Mater. 2005, 79, 165-169. [CrossRef]

13. Ivković, S.; Deutsch, U.; Silberbach, A.; Walraph, E.; Mannel, M. Dietary supplementation with the tribomechanically activated zeolite clinoptilolite in immunodeficiency: Effects on the immune system. Adv. Ther. 2004, 21, 135-147. [CrossRef] [PubMed]

14. Pavelic, K.; Hadzija, M.; Bedrica, L.; Pavelic, J.; Dikic, I.; Katic, M.; Kralj, M.; Bosnar, M.H.; Kapitanovic, S.; Poljak-Blazi, M.; et al. Natural zeolite clinoptilolite: New adjuvant in anticancer therapy. J. Mol. Med. 2001, 78, 708-720. [CrossRef] [PubMed]

15. Sverko, V.; Sobocanec, S.; Balog, T.; Colic, M.; Marotti, T. Natural micronised clinoptilolite mixtures with Urtica dioica L extract as possible antioxidants. Food Technol. Biotechnol. 2004, 42, 189-192.

16. Papaioannou, D.; Katsoulos, P.D.; Panousis, N.; Karatzias, H. The role of natural and synthetic zeolites as feed additives on the prevention and/or the treatament of certain farm animal diseases: A review. Microporous Mesoporous Mater. 2005, 84, 161-170. [CrossRef]

17. Thilsing-Hansen, T.; Jorgensen, R.J.; Enemark, J.M.D.; Iarsen, T. The effect of zeolite A supplementation in the dry period of periparturient calcium, phosphorus and magnesium homeostasis. J. Dairy Sci. 2002, 85, 1855-1862. [CrossRef]

18. Piccione, G.; Alberghina, D.; Marafioti, S.; Giannetto, C.; Casella, S.; Assenza, A.; Fazio, F. Electrophoretic serum protein fraction profile during the different physiological phases in Comisana ewes. Reprod. Domest. Anim. 2012, 47, 591-595. [CrossRef] [PubMed]

19. Piccione, G.; Casella, S.; Giannetto, C.; Panzera, M.; Pennisi, P.; Alberghina, D. Influence of short-term storage on electrophoretic profile of bovine serum proteins. J. Appl. Anim. Res. 2014, 42, 123-125. [CrossRef]

20. Tothova, C.; Nagy, O.; Seidel, H.; Kovac, G. The effect of storage on the protein electrophoretic pattern in bovine serum. Iran. J. Vet. Sci. Technol. 2010, 2, 77-84.

21. Tothova, C.; Nagy, O.; Seidel, H.; Kovac, G. Serum protein electrophoretic pattern in clinically healthy calves and cows determined by agarose gel electrophoresis. Comp. Clin. Pathol. 2013, 22, 15-20. [CrossRef]

22. Zarcula, S.; Cernescu, H.; Mircu, C.; Tulcan, C.; Morvay, A.; Baul, S.; Popovici, D. Influence of Breed, Parity and Food Intake on Chemical Composition of First Colostrum in Cow. Sci. Pap. Anim. Sci. Biotechnol. 2010, 43, 154-158.

23. Bgatova, N.P. Influence of long-term administration of naturally occuring sorbents on the ultrastructure of small intestine enterocyte in rats. Bull. Exp. Biol. Med. 1998, 6, 626-629. [CrossRef]

24. Pârvu, G. Supravegherea Nutriţional-Metabolică a Animalelor; Editura Ceres: Bucureşti, Romania, 1992; pp. 233-248. 
25. Suh, G.H.; Hur, T.Y.; Son, D.S.; Choe, C.Y.; Jung, Y.H.; Ahn, B.S.; Lee, C.Y.; Lee, C.G. Differences in the serum immunoglobulin concentration between dairy and beef calves from birth to 14 days of age. J. Vet. Sci. 2003, 4, 257-260. [PubMed]

26. Piccione, G.; Casella, S.; Giannetto, C.; Vazzana, I.; Niutta, P.; Giudice, E. Influence of age on profile of serum proteins in the calf. Acta Vet. 2009, 59, 413-422.

27. Sadeghi, A.; Shawrang, P. Effects of natural zeolite clinoptilolite on passive immunity and diarrhea in newborn calves. Livest. Sci. 2008, 113, 307-310. [CrossRef]

28. Quigley, J. Passive Immunity in Newborn Calves. Adv. Dairy Technol. 2002, 14, 273-292.

29. Zarcula, S.; Tulcan, C.; Šamanc, H.; Kirovski, D.; Cernescu, H.; Mircu, C. Clinical observations in calves fed colostrum supplimented with clinoptilolite. Sci. Pap. Vet. Med. Timis. 2010, XLIII, 64-69.

30. Šamanc, H.; Kirovski, D.; Adamović, M.; Vujanać, I.; Fratrić, N.; Prodanović, R. Effects of natural zeolite on body weight, weight gain, hematology and biochemical blood parameters in calves. Vet. Glas. 2008, 62, 153-166. [CrossRef]

31. Mumpton, F.A.; Fishman, P.H. The application of natural zeolites in animal science and aquaculture. J. Anim. Sci. 1977, 45, 1188-1203. [CrossRef]

32. Rodriguez-Fuentes, G.; Barrios, M.A.; Iraizoz, A.; Perdomo, I.; Cedre, B. Enterex: Anti-diarrheic drug based on purified natural clinoptilolite. Zeolites 1997, 19, 441-448. [CrossRef]

33. Papaioannou, D.S.; Kyriakis, C.S.; Alexopoulos, C.; Tzika, E.D.; Polizopoulou, Z.S.; Kyriakis, S.C. A field study on the effect on the dietary use of a clinoptilolite-rich tuff, alone or in combination with certain antimicrobials, on the health status and performance of weaned, growing and finishing pigs. Res. Vet. Sci. 2004, 76, 19-29. [CrossRef] [PubMed]

34. Stojić, V.; Gvozdić, D.; Nikolić, J.; Šamanc, H.; Jovanović, I.; Tomašević-Čanović, M.; Vujanac, I. The serum levels of insulin and IGF-1 in newborn piglets treated with clinoptilolite. Acta Vet. 2003, 53, 219-228.

35. Stojić, V.; Gvozdić, D.; Šamanc, H.; Jovanović, I.; Fratrić, N. Thyroid gland hormones in newborn calves treated with clinoptilolite receiving different amounts of colostrum. Acta Vet. 2005, 55, 3-10.

Sample Availability: Not available.

(C) 2018 by the authors. Licensee MDPI, Basel, Switzerland. This article is an open access article distributed under the terms and conditions of the Creative Commons Attribution (CC BY) license (http:/ / creativecommons.org/licenses/by/4.0/). 